AJST

amca2012.org

\title{
Potential of mangrove ecosystem as learning sources of Biology through online learning
}

\author{
Farida Dwi Susanti $1^{1, *}$ \\ ${ }^{1}$ University of Muhammadiyah Malang, Indonesia \\ *Corresponding author: lactobaycus@gmail.com
}

KEYWORDS

Biology

Conservation|| Coast

Distance learning

Mangrove

SUBMITTED 15 Dec 2020

REVISED 5 Jan 2021

ACCEPTED 20 Feb 2021

\begin{abstract}
As an archipelago, Indonesia has thousands of islands and stretched coastlines. It is, therefore, Indonesia has many mangroves as a characteristic of plants exists on the coast. There have been many studies and trials of mangrove utilization for economic and ecological purposes, yet it is limited use of mangroves for educational purposes. This study aims to promote the mangrove ecosystem for educational purposes, particularly as a source of biology learning, increase students 'interest in studying biology, and increase students' interest in conserving mangroves. This study used a qualitative approach with three instruments, namely observation, interview and questionnaire. The result indicated that the mangrove ecosystem could be used as a source of learning biology and be able to increase students' interest in studying biology and conserving mangroves.
\end{abstract}

(c) The Author(s) 2021.

\section{INTRODUCTION}

Mangrove is a vegetation zone located in muddy areas, the confluence of land and sea with tidal influences (Noor et al., 2006). Various species of mangroves are able to grow and develop in coastal environments that are extremely saline and water-saturated; unstable soil conditions and anaerobes are able to develop mechanisms that allow it to actively remove salt from the tissues (Pramudi, 2001). Mangrove has several benefits including ecological and economic benefits. Ecological benefits of mangroves are as a natural protection for abrasion, to accelerate sedimentation, control seawater intrusion, and preserving the areas behind mangroves from high waves and strong winds, spawning grounds, foraging for food, and shelter for fish, shrimp, crabs, and other marine biotas. Meanwhile, sources of food, beverages, medicines, natural dyes, and as ecotourism objects are economic functions (Riwayati, 2014).

Sidoarjo Regency is a delta plain with an altitude between 0 to $25 \mathrm{~m}$, the altitude is 0 to $3 \mathrm{~m}$ with the area of $19.006 \mathrm{Ha}$, where $29,99 \%$ areas are aquaculture that located in the eastern region. The brackish water area in Sidoarjo is located in the east which is directly adjacent to the Madura strait. There is a mangrove ecosystem found in the east area, in which it becomes a typical ecosystem in Sidoarjo Regency (Portal Kabupaten Sidoarjo, 2020). Diversity of mangrove ecosystem in Sidoarjo that located in the east area is formed naturally and artificially, of which ecosystem has a potential to be delivered as learning sources for the students in Sidoarjo Regency. It is expected that it can support the students' knowledge in Sidoarjo Regency since there are a lot of students who do not know well about the potential of mangrove sin Sidoarjo Regency. Identification of mangrove ecosystem located in Lusi Island, Jabon District, Sidoarjo Regency becomes the initial stage of this study. Mangrove vegetation found includes Acanthus ilicifolius, Acanthus ebracteatus, Avicennia alba, Avicennia marina, Rhizopora mucronate, Sonneratia alba, Hippomane mancinella, and Terminalia catappa. From those identification results, biology learning sources from the observation results can be taken in the form of video as teaching material. The use of video media assists the students their learning in developing their learning processes during the Covid-19 pandemic.

The COVID- 19 pandemic is a disaster that has a tremendous impact on the Indonesian population including the world of education and others (Syafrizal, 2020). On January 30, 2020, WHO stipulated the Covid-19 as a Public Health Emergency of International Concern (PHEIC) or a Public Health Emergency Concerning the World (KKMMD). The increase of COVID-19 cases took place quite quickly and spread outside the Wuhan area and other countries. The number of infected cases continues to increase, in which it is quite significantly increased with a relatively fast time. In 6 months, 216 countries in the world have contracted this virus. According to WHO, the number of confirmed cases as of June 25 has reached 9.296.202, with a death rate of 479.433 (WHO, 2020).

Since the COVID-19 pandemic crisis came in March 2020, the Indonesia government decided to close face-toface learning activities in schools and diverted the activities into online learning (daring). On March 24, 2020, the Ministry of Education and Culture of the Republic of Indonesia issued Circular Number 4 of 2020 concerning The 
Implementation of Education Policies in Emergency Times Spread of COVID, in which this circular clarified the learning processes that carried out at home thru an online learning/distance learning to give a meaningful learning experience for the students.

Distance learning, then called as daring (online), becomes a choice when the teaching and learning activities should be continued during the COVID-19 pandemic. Online learning is first introduced by Illionis University thru a computer-based learning system (Riyana, 2020). Online learning is learning carried out face-to-face indirectly by using technologies that can assist the distance teaching and learning process. Online learning gives massive and open network quality learning services to reach more and wider study space enthusiasts (Sofyana \& Abdul, 2019:82). Internet and Learning Management System (LSM)-based interactive model is used in online learning, it can use Zoom, Google Meet, Google Drive, and so on. Webinar and online classes are the example of online learning, in which the whole activities are used internet connection and computer (Hasibuan, Simarmata, and Sudirman, 2019).

Distance learning must still pay attention to the learning objectives (Kurniasari, 2020). The learning objectives should be a reference in establishing what to achieve. One of the ecosystem learning objectives is that the students are expected to be able to discover various kinds of the ecosystems along with their constituent components. Appropriate learning sources can be used to achieve the expected learning objectives. Supriadi (2015) asserts that learning sources are everything in the form of objects or people that can support the learning so that the students can get the impact in the form of behavior changes. Th environment is a learning source that can be directly used. The utilization of the environment by uniting the students directly can improve the students' interests (Irwandi et al., 2019).

The students need to be introduced to various kinds of the ecosystems directly and their constituent components so that those will be easy to understand. The use of local ecosystem ad learning sources can improve the students' productivities (Irwandi, 2019). Local culture existed in the society to preserve mangrove needs to be improved thru a study so that it can support the mangrove forest conservation (Fingkrew, 2015). Integrating local potential by means of utilizing local advantages in each area as a learning source can assist the students to solve the environmental problems and develop their self-potential (Juniati, 2016). A typical local ecosystem needs to be utilized to enrich the students' insights around the ecosystem. From the observation results, the students who recognize the potential of mangroves as a local ecosystem in Sidoarjo Regency are still low. Increased recognition and interest in learning of the potential of the mangrove local ecosystem need to be carried out so that the students of Sidoarjo district can understand the mangrove potential and eventually participate in the mangrove conservation process. The integration of the mangrove ecosystem in biology learning especially in the ecosystem competence will bring out interesting experiences for the students.

During distance learning, proper media are needed so that it can represent the original learning source environment. Tanjung (2020) enlightens that learning media are all forms of intermediaries used to convey messages that can stimulate the thoughts, feelings, and attention of students to achieve the educational goals. According to Mif- tah (2020), the teachers are increasingly being prosecuted to master the technologies related to online learning. The development of media goes after the development of technologies and changing times. The use of various technology applications in media offers an ease and smoothness in the teaching and learning processes. A video as the media utilization can be used to overcome the difficulties in delivering the learning material that sourced from native ecosystems.

Based on the explanation above, research problems that can be formulated encompass: (1) can the mangrove ecosystem be used as a source of biology learning, (2) can the use of mangroves as a biology learning source increase the high school students' interest in learning biology about mangrove vegetation, and (3) can the use of mangroves as a biology learning source increase the high school students' interest to conserve the mangrove vegetation. This study is expected to have several benefits, namely: (1) the use of ecosystem can assist the teachers in delivering the material during the teaching and learning processes, (2) generating the students' interest in learning, (3) increasing the students' knowledge to local ecosystem knowledge, and (4) it can be used as a reference for further similar research or study.

\section{METHOD}

Data collection techniques used are observation, interview, and questionnaire. The observation of mangroves is carried out in the mangrove vegetation at Lusi Island, Jabon District, Sidoarjo Regency, and the students of 10th grade of SMA Negeri 3 Sidoarjo are used as the samples of the study. This study is conducted from September to December 2020. The parameter of students' interest is seen from high and low of students' desire to succeed in learning, looking for supporting references, and active desire in the online learning process. The respondents of this study are the 10th-grade students of SMAN 3 Sidoarjo who participate in online learning during the Covid-19 pandemic. The online method used is by delivering the material and Student Worksheet (LKPD) about the ecosystem and conduct a discussion by means of WA group.

\section{RESULTS AND DISCUSSION}

This study aims: (1) to discover whether the mangrove ecosystem is used as a source of biology learning, (2) to discover whether the use of mangroves as a biology learning source can increase the high school students' interest in learning biology about mangrove vegetation, and (3) to discover whether the use of mangroves as a biology learning source can increase the high school students' interest to conserve the mangrove vegetation.

According to the results of the study, the data of students who appreciate the mangrove as learning sources are obtained, in which it is $90 \%, 87 \%$ of students are interested to learn mangroves, and the students who are able to improve their thinking ability to conserve the mangrove vegetation are $85 \%$.

Lusi island is located in Jabon District, Sidoarjo Regency with coordinates of $7^{\circ} 33^{\prime} 59.30$ "LS (South Latitude) and $112^{\circ} 52^{\prime} 12.74$ "BT (East Longitude); this island is an artificial island that has a lot of mangrove diversity. Mangroves vegetate in the Lusi island naturally during the process of constructing Lusi Island and then its growth is preserved 


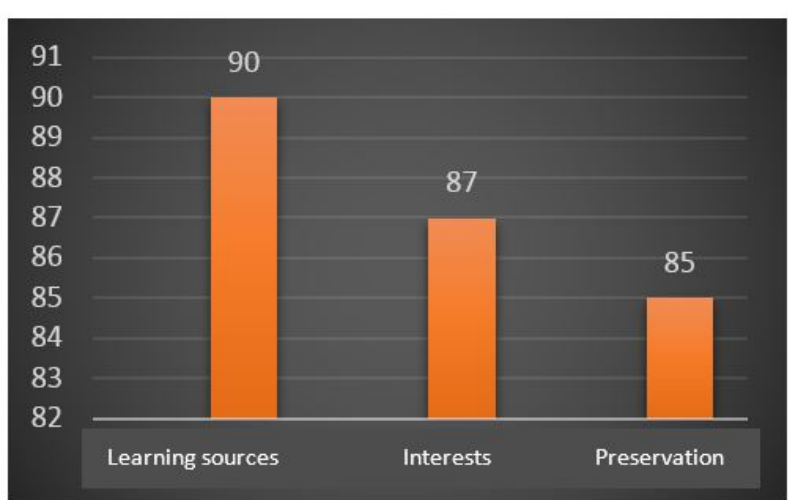

FIGURE 1. The results data of students' questionnaire

by deliberate propagation by the officers from the conservation center.

Mangrove ecosystem that occupies the estuaries and intertidal zones throughout the tropics and subtropics consist of woody plants whose diversity depends on habitat conditions between islands and even the continents (Field, 2010). The diversity of mangrove vegetation existed in Lusi Island, Jabon District, Sidoarjo Regency comprises Acanthus ilicifolius, Acanthus ebracteatus, Avicennia alba, Avicennia marina, Rhizopora mucronate, Sonneratia alba, Hippomane mancinella, and Terminalia catappa, of which diversity can be used as the learning sources. This can be seen from the results of a questionnaire which shows that more than half of the samples like the mangrove ecosystem as learning sources. Local excellence can be a learning source that provides real experiences for students to participate in conserving the local excellence of their region (Sulasih, 2017). The mangrove ecosystem in Lusi island that has mangrove diversity is local excellence that can be used as learning sources. This is in line with the statement of Cahyono (2015) who assumes that the mangrove ecosystem can play a role as a learning source so that it can support the learning process about the ecosystem in biology learning.

The environment is a natural laboratory used as an effective learning source for the students (Haryati, 2016). The use of the environment brings out the students to observe directly, in which it provides a positive impact on the learning development of students (Ikhsan, 2017). The learning observation is implemented online by delivering the material and Student Worksheets (LKPD) about the ecosystem and conducting a discussion thru WA group. From the observation results, $90 \%$ of students can accept the mangrove as a learning source. The students who appreciate to mangrove as a learning source are the students who understand the potential benefits of mangrove, in which it can be developed to be an interesting educational tour. The learning activities carried out using outdoor strategy certainly attract the students' interest and it can improve the learning that has direct meaning with its learning source. According to Setyawan (2006), mangrove area has a potential that can be developed into tourism and education. Sulasih (2017) asserts that outdoor learning activities by utilizing the local excellences can be more fun and can optimize the students' learning achievements.

On the observation of learning interest about mangrove, it obtains a number of $87 \%$, this indicates that there is a level of acceptance from students who like learning us- ing the local mangrove ecosystem in Sidoarjo Regency, especially Lusi Island in Jabon District. The parameters of students' interest can be seen from high and low of students' desire to succeed in the learning, to discover supporting references and to be active in the online learning processes. Interest is a feeling of preference and attachment to something or activity, without being told (Slameto,2013). Interest in learning can be measured from the interest in learning, attention in learning, motivation to learn, and knowledge (Nurhasanah, 2016). High learning interest can make the students be able to learn and train them to think critically and logically (Sirait, 2016).

Ecological material is interested to be delivered in outdoor learning thru direct observation of the ecosystem. However, the conditions during the Covid-19 pandemic do not allow for face-to-face processes so that the learning process was carried out through online learning (daring). Online learning is different from conventional learning where the online learning emphasizes on the accuracy and carefulness of the students in receiving and processing the information presented thru software in the form of data, of which data are sent and storage, as well as accessed at any time (Riyana, 2020). Distance learning needs an assistance from information technologies. The use of internet and multimedia technologies can be used as storage media of knowledge and it can be an alternative of learning in the class (Zhang et al., 2004). The distance learning or online learning can be carried out using internet connection with an accessibility, connectivity, flexibility, and ability to bring out various kiinds of interaction in the learning (Moore et al., 2011). The spread of Corona virus can be suppressed by using an online learning (Sadikin, 2020).

The online learning still needs an interactive activity, yet it is reachable and carried out by all of the students. WhatsApp is used as a media in the interactive learning to discover the mangrove potential. WhatsApp is an internetbased application which is widely used as a communication media since it is easy to be used, cheap, and may features can be used to support the communication (Rahartri, 2019). The teachers get an ease in using the WhatsApp to control the communication activity, send news in the form of text, video, and even images to the students that have been grouped into a WhatsApp group during the learning and outside of the study hours (Anfibar, 2020).

Interesting learning needs an interesting communication facility and learning media. The mangrove ecosystem introduction as learning sources will be more interesting if the students are directly invited to do an observation. During the Covid-19 pandemic, which does not allow the students to observe directly, media assistance is needed so that it can visualize the mangrove object. According to Asfuriyah (2015), a consideration to choose appropriate media can integrate and generate the students' interest to learn more about the topic discussed in the media that cannot be ignored. Suryansyah (2016) clarifies that the use of interesting media can improve the students' concentration and optimize the learning. A learning video is one of the interesting media, of which media can unite the teachers so that the learning is not conventional since there are music, sound, and explanatory illustrations, as well as pictures taken from real conditions that are packaged attractively.

The use of audiovisual media in the learning process that is in accordance with the education procedures and meaningful can improve the motivation and perceptual 


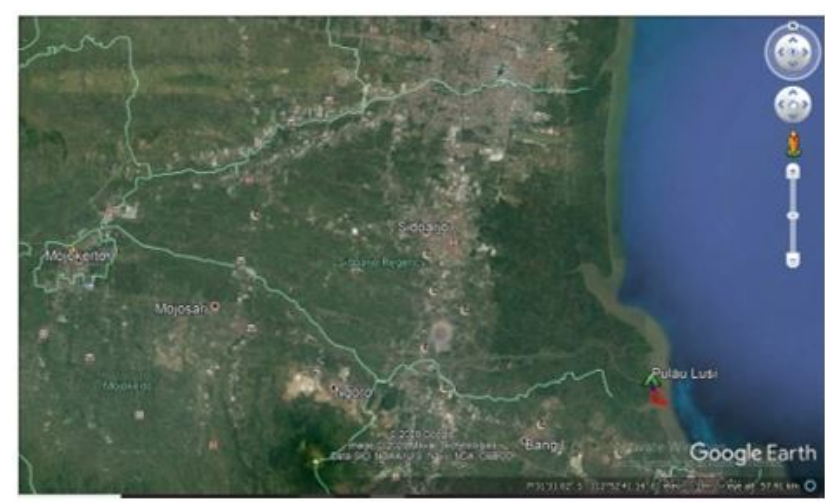

(A)

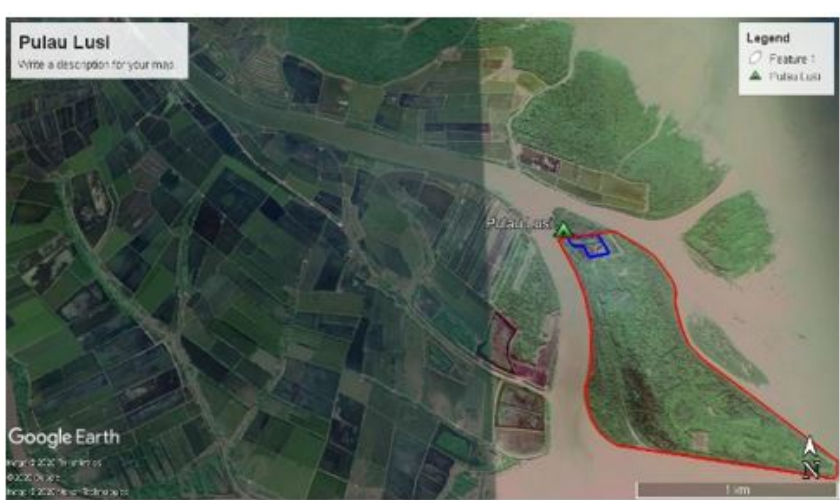

(B)

FIGURE 2. (A) Sidoarjo District taken from google earth and (B) Figure 2. Lusi Island Position

ability so that the earning outcomes increased (Nicolaou, 2019). The use of audiovisual media in an effective way can improve the students' interests and learning outcome (Wahyuni, 2015). High interest can improve the students' learning achievements (Triarisanti, 2019).

Increased interest in student learning about mangroves brings out the impacts on how the students can think about participating in mangrove preservation. After the students adore mangroves in Sidoarjo Regency, the students are increasingly interested in studying mangroves, and in the end, it can improve their thinking skills to be able to conserve the mangrove vegetation.

\section{CONCLUSION}

Departing from the results of the study, it can be concluded that the mangroves ecosystem can be used as biology learning sources. The use of mangrove as biology learning sources can improve the interests of High School (SMA) students in studying biology, especially about mangrove vegetation. The use of mangroves as biology learning sources can improve the interests of High School (SMA) students in preserving the mangrove vegetation.

\section{REFERENCES}

Asfuriyah Siti, Murbangun Nuswowati (2015), Pengembangan Majalah Sains Berbasis Contextual Learning Pada Tema Pemanasan Global Untuk Meningkatkan Minat Belajar Siswa, Unnes Science Education Journal, ISSN 2252-6617, Universitas Negeri Semarang

Anfibar, Dyla Fajhriani N., (2020), Pemanfaatan Whatsapp Sebagai Media Komunikasi Antara Dosen Dan Mahasiswa Dalam Menunjang Kegiatan Belajar (Studi terhadap Mahasiswa UIN Imam Bonjol Padang), AL MUNIR Jurnal Komunikasi dan Penyiaran Islam Volume 11 Nomor 1, Januari-Juni 2020, p. 70-83 p- ISSN : 20861303 e-ISSN : 2657-0521

Cahyono Eko Y., Nana Kariada Tri Martuti (2015), Pengembangan Modul Peranan Ekosistem Mangrove Sebagai Sumber Belajar Berbasis Konservasi Di SMA, Unnes Journal of Biology Education 4 (1)

Field Christopher B. dkk (2010), Mangrove Biodiversity and Ecosystem Function, Global Ecology and Biogeography Letters, Vol. 7, No. 1, Biodiversity and Function of Mangrove Ecosystems (Jan., 1998), Blackwell Publishing, Stable URL: http://www.jstor.org/stable/2997693
Fingkrew Elsye, Ralph Tuhumury dan Dahlan (2015), Pemanfaatan Ekosistem Mangrove Berbasis Kearifan Lokal Di Kampung Nafri Kota Jayapura Provinsi Papua, The Journal of Fisheries Development, Januari 2015 Volume 1, Nomor 2, ISSN 2356 - 1726, e-ISSN 2528 - 3987

Ikhsan Andi, Sulaiman, Ruslan (2017). Pemanfaatan Lingkungan Sekolah Sebagai Sumber Belajar Di SD NEGERI 2 TEUNOM ACEH JAYA, Jurnal Ilmiah Pendidikan Guru Sekolah Dasar FKIP Unsyiah Volume 2 Nomor 1, 1-11 Januari 2017

Irwandi, Hery Fajeriadi (2019). Utilizing the Environment as a Learning Source to Increase Interest and Learning Outcomes of High School Students in the Coastal Region, South Kalimantan, BIO-INOVED : Jurnal BiologiInovasi Pendidikan Vol. 1, No. 2, Juli-Desember, 2019 p-ISSN : 2684-9062 e-ISSN : 2714-9803

Haryati Dini (2016), Efektivitas Pemanfaatan Lingkungan Sekolah Sebagai Sumber Belajar Terhadap Hasil Belajar IPA Peserta Didik Kelas IV SD INPRES BTN IKIP I Makassar, AULADUNA: Jurnal Pendidikan Dasar Islam Vol. 3 No. 2, December 2016, p-ISSN: 2407-2451

Juniati Etika, Winda Purnama Sari (2016), Integrasi Potensi Lokal Pada Pembelajaran Sl Terhadap Pembentukan Learner Softskill Untuk Memecahkan Permasalahan Lingkungan, Prosiding Symbion (Symposium on Biology Education), Prodi Pendidikan Biologi, FKIP, Universitas Ahmad Dahlan, 27 Agustus 2016 p-ISSN: 2540-752x eISSN: 2528-5726

Kurniasari, Asrilia, Fitroh Setyo Putro Pribowo, dan Deni Adi Putra, (2020). Analisis Efektivitas Pelaksanaan Belajar Dari Rumah (Bdr) Selama Pandemi COVID-19. Jurnal Review Pendidikan Dasar: Vol 6, No 3, September 2020 Jurnal Kajian Pendidikan dan Hasil Penelitian http://journal.unesa.ac.id/index.php/PD e-ISSN: 2460-8475

Miftah H. (2020). Fungsi dan Peran Media Pembelajaran Sebagai Upaya peningkatan Kemampuan Belajar Siswa. BPMP Kemendikbud, di unduh dari https://media.neliti.com/media/publications/286890fungsi-dan-peran-media-pembelajaran-seba5babbcd0.pdf tanggal 31 Oktober 2020

Moore, J.L., Camille Dickson-Deane, Krista Galyen, 2011. eLearning, online learning, and distance learning environments: Are they the same? Internet and Higher Education. https://doi.org/10.1016/jiheduc.2010.10.001. 
Nicolaou Constantinos, Maria Matsiola and George Kalliris (2019), Technology-Enhanced Learning and Teaching Methodologies through Audiovisual Media, Education Sciences, MDPI, Educ. Sci. 2019, 9, 196; doi:10.3390/educsci9030196 diakses dari www.mdpi.com/journal/education tanggal 1 Desember 2020

Nurhasanah Siti, A. Sobandi (2016), Learning Interest as Determinant Student Learning Outcomes, Jurnal Pendidikan Manajemen Perkantoran Vol. 1 No. 1, Agustus 2016, Universitas Pendidikan Indonesia

Pramudji (2001), Ekosistem Hutan Mangrove Dan Peranannya Sebagai Habitat Berbagai Fauna Aquatik. Oseana, Volume XXVI, Nomor 4, 2001:13 - 23 ISSN 0216-1877, di unduh dari www.oseanografi.lipi.go.id pada 4 Desember 2020

Portal Kabupaten Sidoarjo diunduh dari http://portal.sidoarjokab.go.id/geografis tanggal 10 Desember 2020 Rahartri (2019), "WHATSAPP" Media Komunikasi Efektif Masa Kini (Studi Kasus Pada Layanan Jasa Informasi Ilmiah Di Kawasan Puspiptek), VISI PUSTAKA Vol. 21, No. 2, Agustus 2019, Pusat Data dan Dokumentasi Ilmiah - Lembaga Ilmu Pengetahuan Indonesia

Riyana C,. (2020), Modul 1 Konsep Pembelajaran On Line, di unduh dari http://www.pustaka.ut.ac.id/lib/wpcontent/uploads/pdfmk/TPEN4401-M1.pdf tanggal 2 Nopember 2020

Riwayati, 2014, Manfaat Dan Fungsi Hutan Mangrove Bagi Kehidupan, Jurnal Keluarga Sehat Sejahtera Vol. 12 (24) Des. 2014 ISSN : 1693 - 1157. Puslitbang KS LPPM Universitas Negeri Medan

Rusila Noor, Y., M. Khazali, dan I N.N. Suryadiputra. (2006) Panduan Pengenalan Mangrove di Indonesia. PHKA/WI-IP, Bogor.

Sadikin Ali (2020). Online Learning in the Middle of the Covid-19 Pandemic. BIODIK: Jurnal Ilmiah Pendidikan Biologi ISSN 2580-0922 (online), ISSN 2460-2612 (print) Volume 6, Nomor 02, di akses dari: https://onlinejournal.unja.ac.id/biodik

Setyawan Dwi A., Kusumo Winarno (2006), The direct exploitation in the mangrove ecosystem in Central Java and the land use in its surrounding; degradation and its restoration effort, BIODIVERSITAS ISSN: 1412-033X Volume 7, Nomor 3 Juli 2006

Simanuhuruk L., dkk. (2019). ELearning: Implementasi, Strategi dan Inovasinya. Medan: Yayasan Kita Menulis.

Sirait Doni E (2016), Pengaruh Minat Belajar Terhadap Prestasi Belajar Matematika, Jurnal Formatif 6(1): 35-43, 2016 ISSN: 2088-351X, Universitas Indraprasta PGRI

Slameto. (2013). Belajar dan Faktor-faktor yang Mempengaruhi. Jakarta: Rineka Cipta. Di ambil dari https://adoc.tips/slameto-belajar-dan-faktor-faktoryang-mempengaruhinya-jakar.html tanggal 26 juni 2016

Sofyana L., Abdul Rozaq, (2019), Pembelajaran Daring Kombinasi Berbasis Whatsapp Pada Kelas Karyawan Prodi Teknik Informatika Universitas Pgri Madiun, Jurnal Nasional Pendidikan Teknik Informatika, ISSN 2089-8673 (Print) | ISSN 2548-4265 (Online) Volume 8, Nomor 1, Maret 2019

Sulasih Bejo, Rodia Syamwil, Saratri Wilonoyudho (2017), Pengembangan Model Pembelajaran Outdoor Study Berbasis Keunggulan Lokal pada Siswa Sekolah Menen- gah Kejuruan, Journal of Vocational and Career Education, JVCE 2 (1) (2017), p-ISSN 2339-0344 e-ISSN 25032305

Supriadi (20150. Pemanfaatan Sumber Belajar Dalam Proses Pembelajaran. Lantanida Journal, Vol. 3 No. 2, di unduh dari jurnal.ar-raniry.ac.id tanggal 31 oktober 2020

Suryansyah Titi, Suwarjo (2016), Pengembangan Video Pembelajaran Untuk Meningkatkan Motivasi Dan Hasil Belajar Kognitif Siswa Kelas IV SD, Jurnal Prima Edukasia Volume 4 - Nomor 2, Juli 2016, Print ISSN: 2338-4743, Online ISSN: 2460-9927

Tanjung, 2020. Buku Ajar Media Pembelajaran, di unduh dari https://www.academia.edu/6481956/Buku_Ajar_Media_Pembelajara tanggal 31 Oktober 2020

Triarisanti Risa, Pupung Purnawarman (2019), The Influence Of Interest And Motivation On College Students' Language And Art Appreciation Learning Outcomes, International Journal of Education Vol. 11 No. 2, February2019, Universitas Pendidikan Indonesia

Wahyuni Tri, Arif Widiyatmoko, Isa Akhlis (2015), Efektivitas Penggunaan Media Audiovisual Pada Pembelajaran Energi Dalam Sistem Kehidupan Pada Siswa SMP, Unnes Science Education Journal, USEJ 4 (3) (2015), Universitas Negeri Semarang, ISSN 2252-6617

WHO Coronavirus Disease (COVID-19) Dashboard di akses dari https://Covid19.who.int/

Zhang, et al. (2004). Can e-learning replace classroom learning? Communications of the ACM.Vol. 47 No.5. 